\title{
EFFECT OF PHYSICAL EXERCISE AND YOGA ON BLOOD PRESSURE AMONG SCHOOL CHILDREN
}

\author{
PREMALATHA ${ }^{1 *}$, KANNIAMMAL $\mathrm{C}^{2}$, VALLI $\mathrm{G}^{3}$, JAYDEEP MAHENDRA ${ }^{4}$ \\ ${ }^{1}$ Department of Nursing, Vee Care College of Nursing, Chennai, Tamil Nadu, India. ${ }^{2}$ Dean, SRM College of Nursing, SRM University, \\ Chennai - 603 203, Tamil Nadu, India. ${ }^{3}$ Department of Pharmacology, Meenakshi Ammal Dental College and Hospital, Chennai, \\ Tamil Nadu, India. ${ }^{4}$ Department of Periodontology, Meenakshi Ammal Dental College and Hospital, Chennai, Tamil Nadu, India. \\ Email: lathaprem_2k2@yahoo.co.in
}

Received: 27 October 2017, Revised and Accepted: 17 November 2017

\section{ABSTRACT}

Objective: The principal aim of the study is to identify the effect of physical exercise and yoga on blood pressure (BP) among children, a common cardiovascular risk factor among children in recent years.

Methods: A true experimental design was adopted to find the effect of physical exercise and yoga on selected children with increased BP and weight. The weight was inferred based on the World Health Organization (WHO) chart on body mass index for age. BP and height were measured and interpreted using the WHO height percentile chart for boys/girls and BP references of National Heart, Lung, and Blood Institute, to identify hypertensive children. Hypertensive children were given physical exercise and yoga, 5 days a week, for 6 months and control group led a normal lives.

Results: In the pretest, $100 \%$ of the study and control group were prehypertensive. After 3 months of physical exercise and yoga, $21 \%$ of study group became normotensive which was significant at $\mathrm{p}=0.000$ and it increased to $93 \%$ after 6 months with the significance of $\mathrm{p}=0.000$. The weight and systolic BP (SBP) had a significant positive correlation. The age $(\mathrm{p}=0.001)$, number of family members, type of family ( $\mathrm{p}=0.01)$, mother's occupation, family history of obesity, and chronic illness among fathers $(\mathrm{p}=0.05)$ had a significant association with SBP of the children.

Conclusion: The study concluded that physical exercise and yoga reduced childhood hypertension as well as is a cost effective and easily practicable intervention for children to minimize cardiovascular risk during their adulthood.

Keywords: Children, Effect, Physical exercise, Yoga, Childhood hypertension, School children.

(C) 2018 The Authors. Published by Innovare Academic Sciences Pvt Ltd. This is an open access article under the CC BY license (http://creativecommons. org/licenses/by/4. 0/) DOI: http://dx.doi.org/10.22159/ajpcr.2018.v11i4.23353

\section{INTRODUCTION}

High blood pressure (BP), a major risk factor of non-communicable diseases (NCD), is a silent killer affects approximately 1 billion people worldwide, and this will increase to 1.56 billion people by the year 2025 [1]. This means 1 out of every 4 adults are being afflicted with hypertension, and it ranks fourth leading cause of mortality and morbidity in the world.

Globally, NCDs cause 7.5 million premature deaths, i.e. $13 \%$ of total deaths each year and accounts for 57 million disability-adjusted life years (DALYs) or 3.7\% of total DALYs [2]. The high BP is one of the major biological/metabolic risk factors of NCDs.

Hypertension is not only a global pandemic but it is also rapidly increasing in developing countries like India. The World Health Organization (WHO) (2012) has already issued a warning that, in India, hypertension affects more than 100 million individuals and $60 \%$ of the world's cardiac patients will be Indian by 2020 . While the awareness of hypertension is poor in India, the treatment and control rates are abnormally low.

Rapid economic development and changes of lifestyle in the past few decades made the prevalence of hypertension, once considered a rare occurrence, reached in alarming proportions among Indian children in the recent years. The prevalence of hypertension among healthy school children aged 10-15 years in Tamil Nadu was $11.4 \%$, and prehypertension was $23.2 \%$, and prevalence of hypertension was found to be higher among obese children (38.5\%) than non-obese $(7.4 \%)[3,4]$.
Several studies [5,6] have reported the tracking effect of BP from childhood to adulthood. Therefore, the tracking and treating of BP in children may have a significant advantage, and it may help to control and possibly prevent high BP before its harmful sequelae can occur [7].

\section{METHODS}

\section{Study design and participants}

A true experimental design was used with multistage cluster sampling technique. From the 16 selected schools from urban and rural zones of Tiruvallur district, Tamil Nadu, the children aged 10-12 years were screened for increased BP and weight.

\section{Sample}

The school children aged 10-12 years, who fell above $85^{\text {th }}$ percentile according to the WHO chart on body mass index (BMI) for age (boys and girls) as well as having $>90^{\text {th }}$ percentile of systolic/diastolic pressure as per the $4^{\text {th }}$ report from National High BP Education Program (NHBPEP) working group on children and adolescents of National Heart, Lung, and Blood Institute (NHLBI) [8] according to sex, age, and height, were selected for the study. Initially, 2581 children were screened for overweight and hypertension. Among those 2581 children, totally 238 children were identified with prehypertension and overweight. By probability - simple random sampling technique, 104 and 97 samples were selected for study for the control group, respectively.

\section{Measurement tools}

The data were collected using structured interview schedule. The demographic details and biophysiological variables such as BP, weight, 
height, and BMI were taken. The average of the three consecutive readings of $\mathrm{BP}$ was taken as the $\mathrm{BP}$ of the child. For BMI and BP, WHO growth charts such as WHO BMI for age chart, height percentile chart for boys and girls and BP references of NHLBI were used to identify children with increased BP and weight [8]. The reliability of the tool was established using test-retest, inter-rater method and its $r$ - values were $0.92(\mathrm{BP})$ and 0.94 (BMI).

\section{Ethical considerations}

The investigator followed the principles of human rights, beneficence, non-maleficence, dignity, confidentiality, and justice. The objective

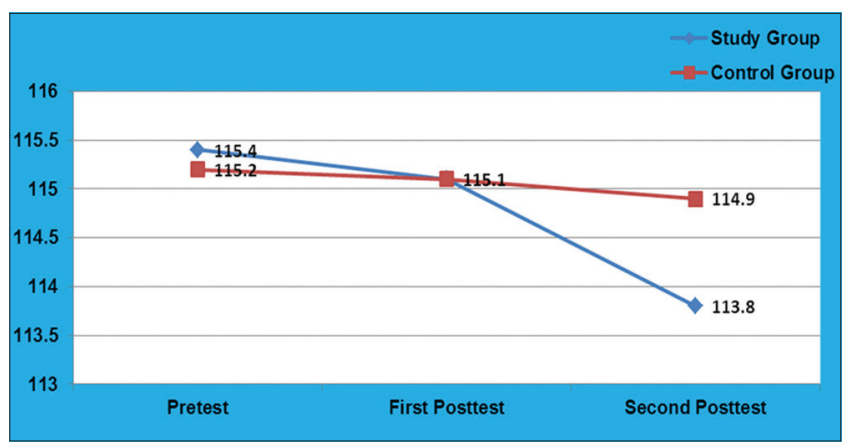

Fig. 1: Comparison of systolic blood pressure among study and control group by RM -ANOVA

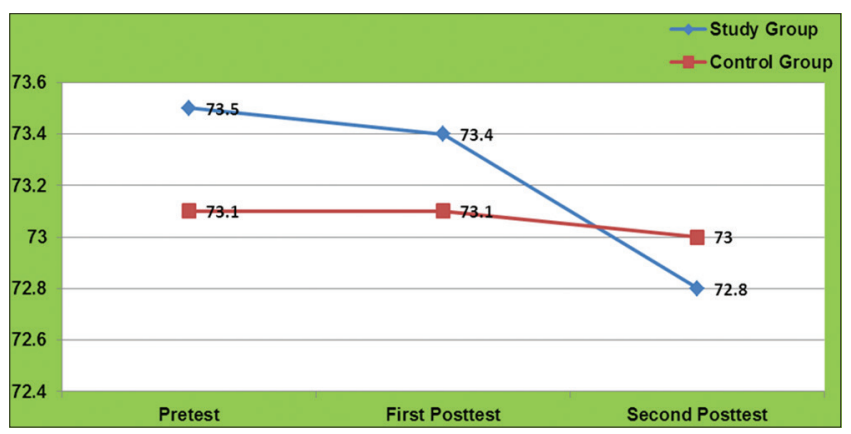

Fig. 2: Comparison of diastolic blood pressure among study and control group by RM-ANOVA of the study was clearly explained to all participants, parents, school authorities and written consent, as well as assent, was obtained. Ethical Committee Approval was received from the institution and permission from the Director, Directorate of Education, Tiruvallur district was obtained. Content validity was received from various experts in the field of pediatrics, pediatric cardiology, community medicine, child health nursing, nutrition and dietetics, yogic science, and statistics. No harm certificate was received from the pediatrician, clinical nutritionists and an expert from yogic science for the intervention. The children of the control group were also given the information booklet related to intervention after the entire data collection process.

\section{Description of intervention}

Physical exercise and yoga were given for 5 days a week which includes 45 min of physical exercise and 15 min of yoga per day. The physical exercise included warm-up, running and chasing, bicycle riding, jumping ropes/hopping, and dancing. The yoga included asana such as forward/backward bending exercises, Ardha Chakrasana of both sides, padahastasana, Yoga Mudhra, Sasangasana, Ustrasana, Supta-Vajrasana, Ardha Matsyendrasana (both sides), Bhujangasana, Matsyasana (each asana for 3 times), and Savasana. This is followed by Nadi Suddi Pranayama of 9 cycles. The reinforcement was given in $2^{\text {nd }}, 6^{\text {th }}$, and $10^{\text {th }}$ weeks as well as $4^{\text {th }}$ and $5^{\text {th }}$ months for the study group. Post-test - 1 and 2 were done after 3 and 6 months of intervention, respectively. Control group led their life under normal circumstances for the entire period of intervention and was provided with the study materials on physical exercise and yoga after data collection.

\section{Statistical analysis}

Frequency, percentage, and mean and standard deviation were used to describe demographic variables. Inferential statistics such as bivariate analysis, correlation coefficient, Chi-square test, paired, unpaired $t$-test, repeated measures ANOVA, and multiple regression analysis for the comparison of scores over a period of time, within and between groups were used to determine the effect, correlate and associate the variables.

\section{RESULTS}

Table 1 summarizes the distribution of demographic variables of children with overweight and hypertension. The test of "Goodness of Fit" among variables showed that majority of the variables was nonsignificant between study and control group which shows that the samples were homogeneous among both the groups.

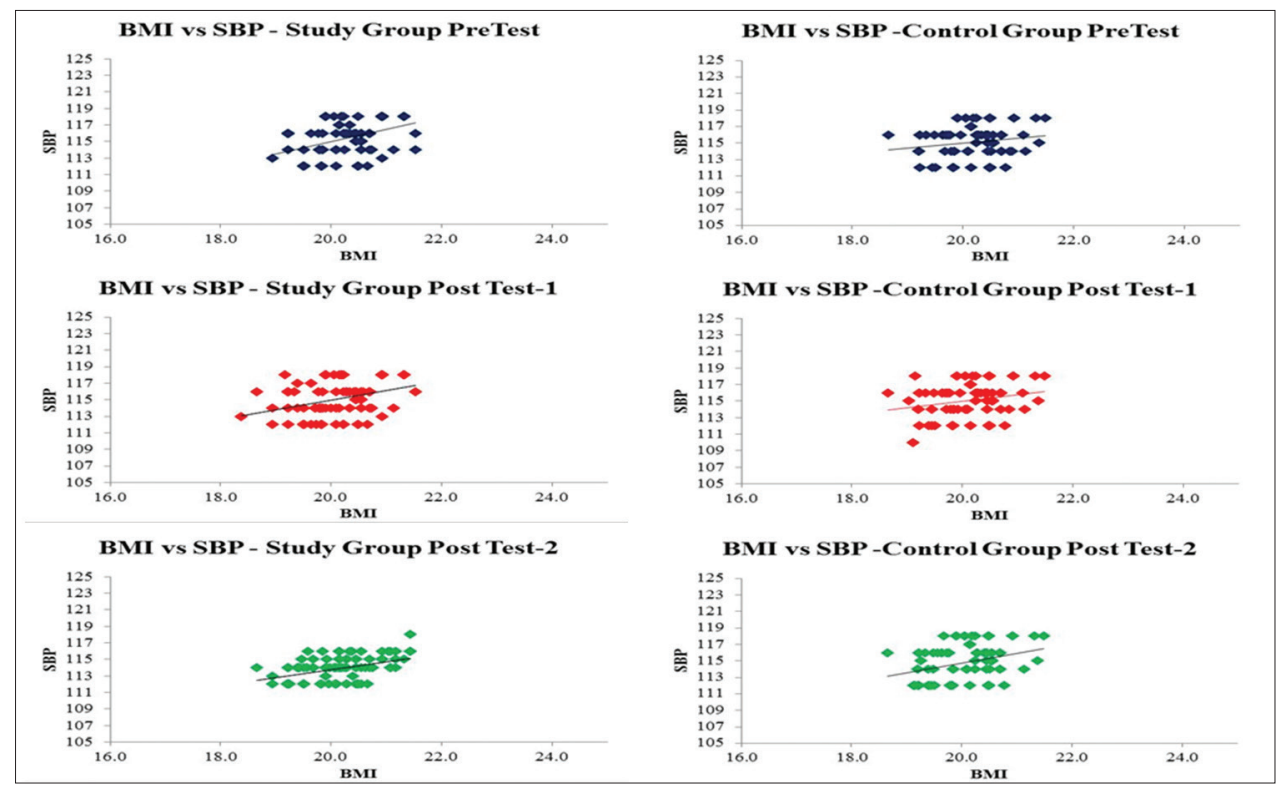

Fig. 3: Relationship between BMI and systolic blood pressure of study and control group 
Table 1: Demographic characteristics of children with overweight and hypertension

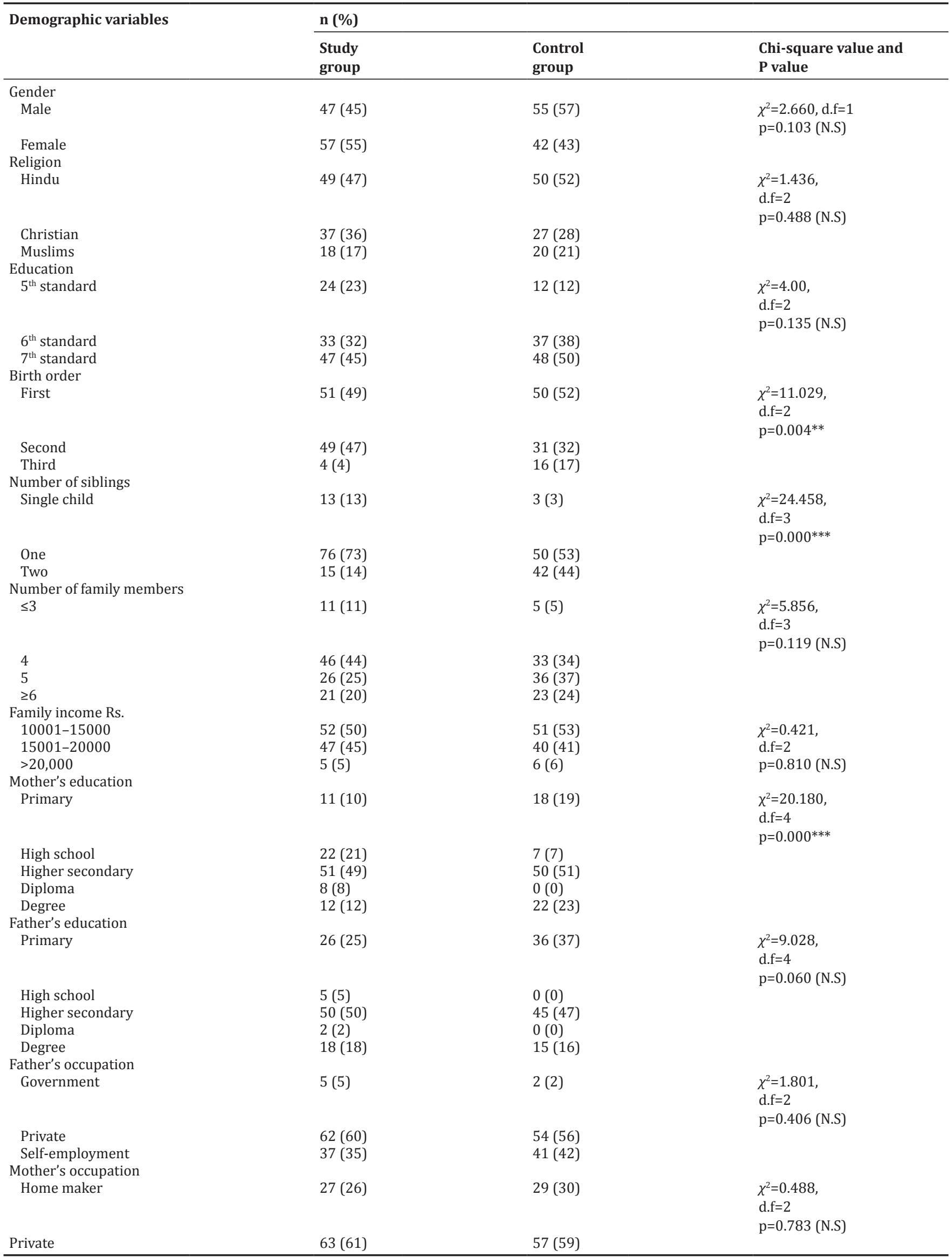


Table 1: (Continued)

\begin{tabular}{|c|c|c|c|}
\hline \multirow[t]{2}{*}{ Demographic variables } & \multicolumn{3}{|l|}{ n (\%) } \\
\hline & $\begin{array}{l}\text { Study } \\
\text { group }\end{array}$ & $\begin{array}{l}\text { Control } \\
\text { group }\end{array}$ & $\begin{array}{l}\text { Chi-square value and } \\
P \text { value }\end{array}$ \\
\hline Self-employment & $14(13)$ & $11(11)$ & \\
\hline \multicolumn{4}{|l|}{ Residence } \\
\hline Urban & $54(52)$ & $51(52)$ & $\begin{array}{l}\chi^{2}=4.00 \\
\text { d.f }=2 \\
p=0.135(N . S)\end{array}$ \\
\hline Rural & $20(19)$ & $23(24)$ & \\
\hline Semi urban & $30(29)$ & $23(24)$ & \\
\hline \multicolumn{4}{|l|}{ Type of family } \\
\hline Nuclear & $68(65)$ & $76(79)$ & $\begin{array}{l}\chi^{2}=4.465 \\
\text { d.f }=2 \\
p=0.107 \text { (N.S) }\end{array}$ \\
\hline Joint & $16(16)$ & $11(11)$ & \\
\hline Extended & $20(19)$ & $10(10)$ & \\
\hline
\end{tabular}

${ }^{* *} \mathrm{p}<0.01,{ }^{* * *} \mathrm{p}<0.001$ level of significant, N.S: Not significant

Table 2: Relationship among BMI, SBP, and DBP of study and control group

\begin{tabular}{lllllll}
\hline \multirow{2}{*}{$\begin{array}{l}\text { Study } \\
\text { periods }\end{array}$} & \multirow{2}{*}{$\begin{array}{l}\text { Correlation } \\
\text { variables }\end{array}$} & \multicolumn{2}{c}{ Study group } & & \multicolumn{2}{c}{ Control group } \\
\cline { 3 - 4 } \cline { 7 - 7 } & & $\mathbf{r}$ & $\mathbf{p}$ & & $\mathbf{r}$ & $\mathbf{p}$ \\
\hline Pre-test & BMI and SBP & 0.412 & $0.000^{* * *}$ & & 0.169 & 0.099 \\
& BMI and DBP & 0.01 & 0.918 & & 0.004 & 0.973 \\
First & BMI and SBP & 0.355 & $0.000^{* * *}$ & & 0.0222 & $0.29^{*}$ \\
post-test & & & & & \\
Second & BMI and DBP & 0.052 & 0.607 & & 0.005 & 0.959 \\
post-test & BMI and SBP & 0.421 & $0.000^{* * *}$ & & 0.0339 & $0.30^{*}$ \\
& & & & & & \\
& BMI and DBP & 0.134 & 0.191 & & 0.002 & 0.982 \\
\hline
\end{tabular}

${ }^{*} \mathrm{p}<0.05,{ }^{* *} \mathrm{p}<0.01,{ }^{* * *} \mathrm{p}<0.001$ level of significant. BMI: Body mass index, SBP:

Systolic blood pressure, DBP: Diastolic blood pressure

For the study group, in the pre, first and second post-test, BMI and systolic BP (SBP) showed a significant positive correlation at $p=0.000$, which proves that BMI is strongly correlated with BP. It emphasizes that there is the greatest need for prevention, early diagnosis and weight management among children to have a significant reduction in BP. Although there is no significance, BMI and DBP have a positive correlation which proves that if BMI increases DBP increases (Table 2)

The ANOVA test findings in Table 3 revealed that there was statistically significant association found between the demographic variable such as age, number of family members, type of family, mother's occupation, and family history of obesity and chronic illness among fathers had a significant association with SBP of the children in pre-test. Family history of obesity and chronic illness among fathers had a significant association with DBP also.

\section{DISCUSSION}

The comparison of BP status for study and control group children showed that after 3 months of intervention, 21 (21\%) study group children became normal whereas it was increased 90 children (93\%) after 6 months which was statistically significant at $p=0.000$. In control group, only $8(8 \%)$ children became normotensive after 6 months of intervention. The comparison of Systolic and diastolic blood pressure among study and control group is shown in Fig. 1 and Fig. 2. Several studies [9-12] illustrated the similar findings that the exercise and yoga showed significant improvement on BMI and SBP. These results highlighted the importance of multidisciplinary approach including physical exercise and yoga for the treatment of childhood hypertension, overweight/obesity and emphasized its encouraging long-term positive effects. The comparison of the effective score for BP between study and control group as shown in Table 4 revealed that the intervention should
Table 3: Association between SBP and demographic variables of study group

\begin{tabular}{|c|c|c|c|c|}
\hline \multirow[t]{2}{*}{ S. No. } & \multirow{2}{*}{$\begin{array}{l}\text { Demographic } \\
\text { variables }\end{array}$} & \multicolumn{3}{|c|}{ SBP in pre-test } \\
\hline & & $\mathbf{n}$ & Mean \pm SD & $\begin{array}{l}\text { ANOVA F and } \\
P \text { value }\end{array}$ \\
\hline \multirow[t]{4}{*}{1} & Education & & & \\
\hline & $5^{\text {th }}$ standard & 24 & $114 \pm 2.4$ & $\mathrm{~F}=11.94 \mathrm{P}=0.000^{* * *}$ \\
\hline & $6^{\text {th }}$ standard & 33 & $115 \pm 2.1$ & \\
\hline & $7^{\text {th }}$ standard & 47 & $116 \pm 1.4$ & \\
\hline \multirow[t]{5}{*}{2} & $\begin{array}{l}\text { Number of } \\
\text { family members }\end{array}$ & & & \\
\hline & $\leq 3$ & 11 & $116 \pm 1.2$ & $\mathrm{~F}=4.354 \mathrm{P}=0.006^{* *}$ \\
\hline & 4 & 46 & $116 \pm 2.2$ & \\
\hline & 5 & 26 & $115 \pm 2.4$ & \\
\hline & $\geq 6$ & 21 & $115 \pm 0.9$ & \\
\hline \multirow[t]{4}{*}{3} & $\begin{array}{l}\text { Mother's } \\
\text { occupation }\end{array}$ & & & \\
\hline & Home maker & 27 & $116 \pm 1.8$ & $\mathrm{~F}=4.59 \mathrm{P}=0.012^{*}$ \\
\hline & Private & 63 & $115 \pm 2.1$ & \\
\hline & Self-employed & 14 & $115 \pm 1.7$ & \\
\hline \multirow[t]{4}{*}{4} & Type of family & & & \\
\hline & Nuclear & 68 & $116 \pm 2.1$ & $\mathrm{~F}=6.72 \mathrm{P}=0.002^{* *}$ \\
\hline & Joint & 16 & $114 \pm 1.8$ & \\
\hline & Extended & 20 & $115 \pm 1.6$ & \\
\hline \multirow[t]{6}{*}{5} & $\begin{array}{l}\text { Family history of } \\
\text { obesity }\end{array}$ & & & \\
\hline & No & 94 & $115 \pm 2.1$ & $\mathrm{~F}=2.791 \mathrm{P}=0.030^{*}$ \\
\hline & Father & 2 & $112 \pm 0$ & \\
\hline & Mother & 1 & $116 \pm 0$ & \\
\hline & Grandparents & 1 & $117 \pm 0$ & \\
\hline & Relatives & 6 & $117 \pm 1$ & \\
\hline \multirow[t]{5}{*}{6} & Chronic & & & \\
\hline & $\begin{array}{l}\text { 1Ilness-father } \\
\text { Nil }\end{array}$ & 92 & $115+2$ & $\mathrm{~F}=3.083 \mathrm{P}=0.031^{*}$ \\
\hline & DM & 9 & $117 \pm 2$ & \\
\hline & HT & 2 & $116 \pm 0$ & \\
\hline & Asthma & 1 & $118 \pm 0$ & \\
\hline
\end{tabular}

${ }^{*} \mathrm{p}<0.05,{ }^{* *} \mathrm{p}<0.01,{ }^{* * *} \mathrm{p}<0.001$ level of significant, N.S: Not significant. DM:

Diabetes mellitus, SBP: Systolic blood pressure, SD: Standard deviation

be long-term to bring the desired change in DBP than SBP which is also consistent with various study findings [13-16].

The significant association between BP and demographic variables highlighted that the age, number of family members, type of family, mother's occupation, and family history of obesity and chronic illness among fathers should be considered as risk factors of hypertension among children and those children to be screened periodically to 
Table 4: Comparison of effective score for BP among children of study and control group

\begin{tabular}{|c|c|c|c|c|c|c|c|c|c|c|}
\hline \multirow{3}{*}{$\begin{array}{l}\text { Effect } \\
\text { Period }\end{array}$} & \multicolumn{5}{|l|}{ SBP } & \multicolumn{5}{|l|}{ DBP } \\
\hline & \multicolumn{2}{|c|}{ Study group } & \multicolumn{2}{|c|}{ Control group } & \multirow{2}{*}{$\begin{array}{l}\text { Independent } \\
t \text { and } P \text { value }\end{array}$} & \multicolumn{2}{|c|}{ Study group } & \multicolumn{2}{|c|}{ Control group } & \multirow{2}{*}{$\begin{array}{l}\text { Independent } \\
t \text { and } P \text { value }\end{array}$} \\
\hline & Mean (SD) & $\begin{array}{l}\text { Paired } t \\
\text { and } P \text { value }\end{array}$ & Mean (SD) & $\begin{array}{l}\text { Paired } \\
t \text { and } \\
P \text { value }\end{array}$ & & Mean (SD) & $\begin{array}{l}\text { Paired } t \\
\text { and } P \text { value }\end{array}$ & Mean (SD) & $\begin{array}{l}\text { Paired } \\
t \text { and } \\
P \text { value }\end{array}$ & \\
\hline $\begin{array}{l}\text { Pre to } \\
\text { first } \\
\text { post-test }\end{array}$ & $0.27(0.96)$ & $\begin{array}{l}\mathrm{t}=2.81 \\
\mathrm{P}=0.006^{* * *}\end{array}$ & $0.08(0.57)$ & $\begin{array}{l}\mathrm{t}=1.1 \\
\mathrm{P}=0.16\end{array}$ & $\begin{array}{l}\mathrm{t}=1.66 \\
\mathrm{P}=0.10\end{array}$ & $0.09(0.34)$ & $\begin{array}{l}\mathrm{t}=2.23 \\
\mathrm{P}=0.03\end{array}$ & $0.03(0.2)$ & $\begin{array}{l}t=1.00 \\
P=0.32\end{array}$ & $\begin{array}{l}\mathrm{t}=1.67 \\
\mathrm{P}=0.10\end{array}$ \\
\hline $\begin{array}{l}\text { Pre to } \\
\text { second } \\
\text { post-test }\end{array}$ & 1.57 (1.53) & $\begin{array}{l}\mathrm{t}=9.93 \\
\mathrm{P}=0.000^{* * *}\end{array}$ & $0.31(1.01)$ & $\begin{array}{l}\mathrm{t}=2.35 \\
\mathrm{P}=0.03^{*}\end{array}$ & $\begin{array}{l}\mathrm{t}=6.62 \\
\mathrm{P}=0.000^{* * *}\end{array}$ & $0.69(1.26)$ & $\begin{array}{l}t=5.39 \\
P=0.000^{* * *}\end{array}$ & $0.12(0.75)$ & $\begin{array}{l}t=1.617 \\
P=0.11\end{array}$ & $\begin{array}{l}\mathrm{t}=3.801 \\
\mathrm{P}=0.000^{* * *}\end{array}$ \\
\hline
\end{tabular}

${ }^{* * *} \mathrm{p}<0.001$ level of significant, N.S: Not significant. SBP: Systolic blood pressure, DBP: Diastolic blood pressure, SD: Standard deviation

prevent and control BP. As there is a tracking effect of BP in children into adulthood, halting the menace of childhood itself will benefit the entire society from the tentacles of NCDs.

\section{CONCLUSION}

The present study concludes that the physical exercise and yoga significantly reduced SBP in children but necessitates a long-term intervention with appropriate reinforcement to bring the desired change in DBP. Weight and SBP showed a significant positive correlation $(\mathrm{p}=0.000)$ as shown in Fig. 3, which emphasises the importance of weight management among hypertensive children. The demographic variables such as age and family history of hypertension, diabetes mellitus, and chronic illness among family members showed highly significant association with BP which highlights the need for early screening and treatment of children for hypertension as a means of primordial prevention of NCDs.

\section{AUTHORS CONTRIBUTIONS}

Premalatha P developed the study, did data collection, data analysis and wrote the first draft of the paper. Also, she rectified and approved the final manuscript. Kanniammal $C$ read and approved the final manuscript. Valli G, read and sanctioned the first draft. Jaydeep Mahendra read and sanctioned the first draft.

\section{CONFLICTS INTERESTS}

The authors declare that there is no conflict of interest.

\section{REFERENCES}

1. Sujatha T, Judie A. Effectiveness of a 12-week yoga program on physiopsychological parameters in patients with hypertension. Int $\mathrm{J}$ Pharm Clin Res 2014;6:329-35.

2. Available from: http://www.who.int/gho/publications/world_health statistics/2017/en.

3. Harini G, Fathima NJ, Bharathi S, Prabu EP. Prevalence of hypertension among healthy school going children and correlation with anthropometric indices. Int J Res Med Sci 2016;4:3455-8.

4. Sudha R, Thomas C. Blood pressure distribution and its association with anthropometric measurements among Asian Indian adolescents in an urban area of Tamil Nadu. Int J Med Sci Public Health 2014;3:1100- 4.

5. Sarin D, Chaturvedi P. Normal blood pressure and prevalence of hypertension in school going children. J MGIMS 1997;1:32-5.

6. Prabhjot A, Kaur N, Kumari K, Sighu S: Variation in blood pressure among school children in Amristar (Punjab). Anthropologist. 2005, 7: 201-4.

7. Munter P, He J, Cutler JA, Wildman RP, Whelton BK. Trends in blood pressure among children and adolescents. JAMA 2004;291:2107-13.

8. National High Blood Pressure Education Program Working Group on High Blood Pressure in Children and Adolescents. The $4^{\text {th }}$ Report on the Diagnosis, Evaluation, and Treatment of High Blood Pressure in Children and Adolescents. Pediatrics 2004;114 2:555-76.

9. Chu P, Gotink RA, Yeh GY, Goldie SJ, Hunik MG. The effectiveness of yoga in modifying risk factors for cardiovascular disease and metabolic syndrome: A systematic review andmeta-analysis of randomized controlled trials. Eur J Prev Cardiol 2016;23:291-307.

10. Lone DK, Thakre SS, Borkar AM, Deshmukh NN, Thakre SB. Anthropometric correlates of blood pressure among school children in Nagpur city, central India: A cross-sectional study. Int J Med Public Health 2014;4:10634.

11. Ghosh S, Dent R, Harper ME, Gorman SA, Stuart JS, McPherson R. Gene expression profiling in whole blood identifies distinct biological pathways associated with obesity. BMC Med Genomics 2010;1:56.

12. Priya JV, Kanniammal C, Jaideep M, Valli G. Impact of yoga on blood pressure and quality of life in patients with hypertension. Int J Pharm Clin Res 2017;9:413-6

13. Therese AM, Praveena R, Murali R. Yoga: Effective therapy to reduce blood pressure among hypertensive clients. Int $\mathrm{J}$ Dev Res 2017;6:7761-5.

14. Mahajan AS. Role of yoga in hormonal homeostasis. Int J Clin Exp Physiol 2014;1:173-8.

15. Mizuno J, Monteiro HL. An assessment of a sequence of yoga exercises to patients with arterial hypertension. J Bodywork Move Ther 2013;17:35-41.

16. William BS, Robert MM, Blimkie CJ, Stephen RD, Rodney KD, Bernard G, et al. evidence based physical activity for school-age youth. J Pediatr 2005;146:732-7. 